IRSTI 06.81.55

UDC 659

https://doi.org/10.46914/1562-2959-2021-1-3-57-64

\author{
A.P. SADULLAEVA, *1 \\ Master of sciences, PhD student. \\ *e-mail: sp-aigul@mail.ru \\ G.K. BAIZHAKSYNOVA, ${ }^{1}$ \\ c.e.s., associate professor. \\ ${ }^{1}$ Narxoz University, Kazakhstan, Almaty
}

e-mail: gulshat.baizhaksynova@narxoz.kz

\title{
ON THE CITY BRAND DEVELOPMENT: CITY STYLE AS A CITY BRAND DIMENSION
}

\begin{abstract}
The article discusses the issues of the development of the city brand. The main purpose of the study was to identify the factors and components that contribute to the development of the city brand. The city brand model of Thomas Gad has been taken as a theoretical basis of the study. This model describes four dimensions of a city brand: mental, spiritual, social and functional. The author of the article has made an attempt to describe and add one more dimension to above-mentioned model-the dimension of "city style" with its visual and aesthetic aspect. The literature review has been conducted in order to clarify the concepts of "brand" and "city brand". The questionnaire has been carried out among residents of two cities of Kazakhstan to identify the influence of the city style on the recognition of the city. The above is the theoretical and practical contribution of this study to the development and formation of the city's brand. The proposal of the author of the study to develop design codes for cities of the Republic of Kazakhstan is of applied importance.
\end{abstract}

Key words: city brand, dimensions, brand awareness, model, branding, city style, design-city code.

\section{Introduction}

An increased attention of researchers and practitioners to the formation and development of city brands is due to several reasons. Firstly, mass media influences the way how citizens perceive and understand city brands. Secondly, an increased interest of many parties has created the need to use branding technologies in city management.

The notion of the city brand has now become a common trend, which is determined by the increasing competition of territories for attracting resources in the context of globalization. At the same time, brands of larger territorial entities are subsequently formed around cities. This is due to the following reasons:

- Cities are the centers of local cultures, forming the mentality of the population.

- City advertising is becoming an effective tool for strengthening the economy. It contributes to the emergence of the so-called world cities (global cities).

- The image of the city is always diverse, and this is its advantage. The city is its famous citizens and a unique history, architectural appearance and local products. Each city is unique and helps to shape and maintain the uniqueness of the brand.

- The city brand is the most stable of all types of brands; it is less exposed to political and economic risks [1].

\section{Article aim}

The aim of the article is to study the city brand dimensions and to offer the city style as an additional dimension to the concept of the city branding. 


\section{Article objectives}

This article contributes to the body of knowledge in the field of marketing, especially in the area of the city brand development and formation. The objectives of the study are: to conduct the literature review and to analyze various definitions of the city brand related terms, to conduct a questionnaire and examine the notion of the city style that can serve as a dimension to the concept of the city branding. The theoretical contribution lies in the fact that some efforts have been done to identify the importance of the city style in the city brand recognition and a practical implication is in the recommendation for Kazakhstan cities to implement the programs of city design codes that have been successfully used and verified in many well-known cities of the globe.

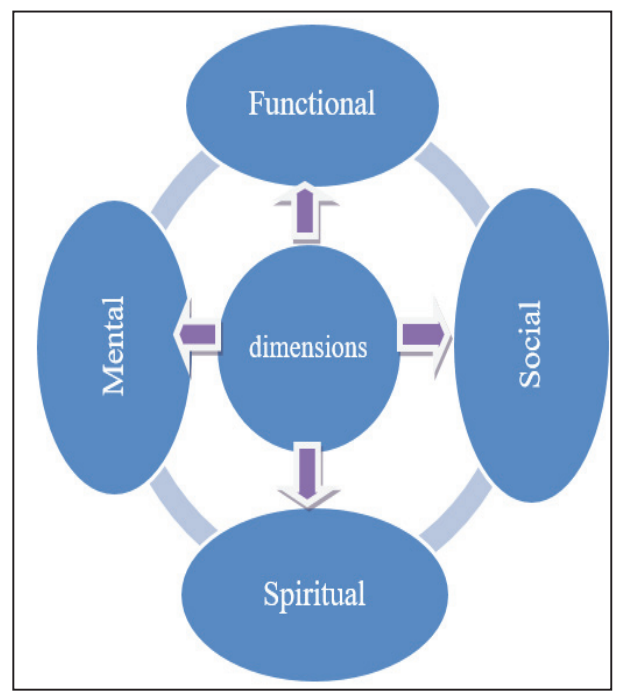

\section{History}

This section starts with a brief description of Thomas Gad's city brand model. Thomas Gad in his book "4-D Branding: Cracking the Corporate Code of the Network" proposed the city brand model that comprises of four different dimensions. These are: functional dimension, social dimension, spiritual dimension and mental dimension (Figure 1).

Figure 1 - City brand model by Thomas Gad

Note - based on source [2].

The city brand model will be taken as a theoretical basis of the article. Further studies will describe the author's intention to add one more dimension to this model with the aim to expand it and with the aim to point out the importance of the city style in the recognition of the city that can help to promote the city brand. However, prior to defining the "city brand" term, it is necessary to identify the meaning of the "brand" definition.

According to Pierre [3] the brand is an image in the consumer's mind of functional and psychological features. As for the American Marketing Association [4] brand is a name, symbol, design, or a blended mix of them, with the intention to distinguish the products and services of one seller from a group of sellers. Also, it is possible to define brand as a combination of material and immaterial attributes aimed to provide knowledge and identity as well as to create a reputation for a product, service, individual, place, or organization [5].

Brands are ubiquitous; they infiltrate nearly every aspect of our life: economic, social, cultural, sporting, even religion. Because of their tendency to penetrate everywhere they have become the object of increasing criticism. In post-modern societies where people are willing to give names to their consumption, brands may and ought to be analyzed through different viewpoints: macro-economics, sociology, anthropology, history, semiotics, philosophy and so forth [6].

As for the definition of the term "city brand", N. Nickerson and R. Moisey [7] describe it as creating relationships between citizens and the image of their city.

Derivation of a 'city brand' definition from a 'nation brand' has been proposed by other field contributors. In this respect, a nation brand has been characterized as "the exceptional multidimensional mix of elements that provide cultural differentiation and relevance to the nation for all its target audiences [8].

The branding of sites and cities in particular has achieved extraordinary traction among city officials. For this reason, marketers aim to identify the city as a brand has been placed, so as to promote existing and potential target units; and distinguish themselves from others, to uphold their identity for achieving various economic, political or socio-psychological aims [9]. 
In addition to the definitions of the "brand" and "city brand" it is useful to learn about such terms as - destination branding, city branding and nation brand.

When it comes to the definition of the term - "destination branding", it should be said that its meaning has evolved over the past forty years and several concepts have emerged such as the place branding, city branding, town branding etc with their focus on a various spatial scale. It is about identification the strongest and most competitive assets of a destination in the eyes and minds of tourists $[10,11]$.

City branding is an effort to create and enrich the city's qualities. City branding is associated with a marketing practice in which city officials and their representatives design a symbol or create a name that can be easily identified by others [12].

A nation brand is not only specific goods produced in the country, but also all symbols, names and attractions and sightseeing. National branding is an area of knowledge and practice that aims to measure, build and manage the reputation of countries. National branding is closely related to the concept of place marketing (territorial marketing) [13, 14].

Due to the severe competition in a modern world it is time to search for better approaches to enhance the picture of the city in order to attract visitors. Based on the literature review, the author has come to the conclusion that destination branding on the whole and the city branding particularly remain at their earliest stages implying that these fields can be studied further.

\section{Research methods}

Several sources were employed to collect data for this article: a brief exploratory questionnaire was used with the aim to understand the opinions and attitudes of citizens regarding the notions of "city style" and "city brand" and to identify the citizens' opinions if the city style affected the recognition of the city - this was the first source of data. The second sources of data were Internet and publicly available newspapers and online websites. These sources were needed to compare the information regarding city styles and city brands in many territorial and urban places. Furthermore, data for the research came from scientific articles and official reports.

The research question was - "Do citizens think that there is a connection between the notions of city style and city recognition". The hypothesis was around the following statement: "there is a relationship between the city style and the city recognition".

The author used a "convenience approach" to conduct questionnaire and the respondents were selected because they were available and accessible. The questionnaire was designed from the literature reviews and analysis from different cities website content. The identities of respondents were not disclosed, they were kept confidential. An online questionnaire in Russian language was prepared and sent to the emails of citizens in the cities of Almaty and Shymkent in the Republic of Kazakhstan with a cover letter, to a total sample of 232 respondents. However, the response rate was of $48.3 \%$ with $n=112$ full replies with 0 missing values. Out of 112 replies, 80 respondents were from the city of Almaty $(71,4 \%)$ and 32 citizens from the city of Shymkent $(28,5 \%$ respectively). The questionnaire was carried out in summer 2020.

The cities of Almaty and Shymkent were chosen because the author of the article has some professional ties with these cities and because they are the country's largest cities with population of over a million. These two facts are important: professional ties help to reach out more people and since it is stated that the city style and city recognition notions are under the study, it is argued that citizens of larger cities may be more prone to express their opinions regarding these notions.

The questionnaire was analyzed and presented in a descriptive style. First of all, the author analyzed the statistical data, and then emerging concepts were grouped into categories. The authors compared the data with data found in the literature review [15].

Since the recognition of the city also relates to one of the characteristics of the city's brand, it is argued that the city style affects the recognition of the city. Therefore, the aim of the questionnaire was to determine the opinions of citizens of two cities regarding their understanding of the concepts of "city style" and "city brand", as well as to identify their opinions on whether the city style affected 
the recognition of the city. This was an introductory questionnaire that consisted of five questions and underlying implications required for further studies.

In response to the question: "What is your understanding about the concept - "the city style", $27 \%$ of respondents reported that "the city style for them is a manifestation, recognition of an image that is well recognized by residents of the city, it is also an image that is unique and creates conditions to distinguish one city from other cities". $9 \%$ of respondents answered that the style of the city for them means the "soul" of the city, and that because of this the city has its own appearance and uniqueness. $19 \%$ of respondents said that by the style of the city they understood an identical design of urban objects, such as benches, lamps, lawns, sizes and colors of garbage bins and shop windows. 39\% of respondents said that the style of the city was both the image and the unified design of urban objects. The remaining $6 \%$ refrained from responding.

The answers to the question: "Is there any city style in the place where you reside?" were as follows: $59 \%$ of respondents said that their city did not possess a style. $15 \%$ of respondents said that their city was green and clean and claimed those attributes to be their city style. $26 \%$ respondents found it difficult to answer this question.

To the question: "Would you like your city to have its own (distinct) style?" $58 \%$ of respondents said that they would like to have a unified architectural style in the city in which they live, they want more modern buildings, parks and places of entertainment, and that these places should be appropriately decorated in a single style. $10 \%$ of respondents said that they did not want to change anything in the style of their city, whereas $15 \%$ of respondents said that their city already had a style. $17 \%$ found it difficult to answer this question, the reasons are unclear.

To the forth question: "Do you think that the concepts of "city brand" and "city style" are interrelated? $46 \%$ of respondents said that definitely was a connection in these terms, $21 \%$ said that there was no interrelation between the aforementioned terms, and the remaining respondents found it difficult to provide an answer to this question.

To the fifth question: "Does the style of the city affect the recognition of the city?" a major portion of respondents agreed that the style of the city affected the recognition of the city (77\%), $16 \%$ of respondents replied that the style of the city did not affect the city's recognition fact and the remaining $5 \%$ of surveyed people found it difficult to answer this question.

The author of the article hypothesized that the city style had a relationship to the recognition of the city. Since recognition is an element of people's knowledge about a brand [16], it is stated by the author of the article that the city style is an important element of the city brand. It has been identified that majority of respondents (59\% that constitute 66 people out of 112 surveyed) in two major cities of Kazakhstan state that their cities do not have a distinct city style. Citizens have expressed positive attitude to the idea of their own cities to have its style $(58 \%, n=65)$. Moreover, it appears that the city style comprises the image of the city, its design and architectural views for the respondents $(39 \%$, $\mathrm{n}=44$ ). Majority of respondents state that there is an interrelation between the concepts of "city brand" and "city style" $(46 \%, n=52)$. Respondents of both cities have stated that the style of the city affects its recognition $(77 \%, \mathrm{n}=86)$.

\section{Results and discussion}

Hence, this article started with a literature review on the main concepts of the topic. The review was about various definitions of the terms - "brand" and "city brand". This review was needed in order to explain and understand the notions of brand in terms of its usage in respect to cities and identify different views of researchers regarding multifaceted dimensions of brands.

Joseph Newman defines brand as everything that people associate with it [17]. F. Clark states that customers pay attention to the brand value and find it important in their personal experience [18]. As for the brand of the city, it must be said, that K. Dinnie in 2011 identifies it as a unique mix of elements based on culture and targeted on special types of audiences [19]. City brand allows differentiating one city from another and in pursuit of reaching uniqueness stands for positioning the city as a place of living that satisfies the needs of its citizens and tourists: be it economical, political, and social etc. 
Since this article is focused on examining the measure of the city brand, the modeling of Thomas Gad has been taken as a theoretical foundation for the study. It is also stated in the article that brand awareness and brand knowledge consisting of brand recognition and brand recall performance, according to $\mathrm{K}$. Keller and the city style has a relation to the recognition of the city.

The questionnaire has been conducted with the aim to determine the citizens' opinions if the city style affected the recognition of the city. Majority of respondents have stated that the city style affected the recognition of the city and the extant literature on this topic provides evidences on this fact [20].

This way, the author of the article offers one more dimension to Thomas Gad's city brand model the city style. The city style is understood as a manifestation and recognition of a city image that is close to the inhabitants of the city. It is an image that would attract tourists, city guests and investors. The city style comprises of the city's architectural image and visual-aesthetic aspects of the city objects.

It is argued in the article that from the position of target consumers, a city's brand is formed under the influence of the following components:

- city status;

- urban folklore;

- stereotypes about the city;

- urban mythology;

- emotional connections with the city (emotions, feelings, expectations, hopes associated with the city, and attitude to it);

- urban symbols (name, flag, coat of arms, emblem, motto, anthem, etc.).

- the appearance of the city [21].

Out of these components, the author states that the appearance of the city and urban symbols relate to the style of the city and its visual-aesthetic aspect. A unified styling of urban objects such as city garbage bins, lanterns, benches, irrigation ditches, bus stops and even the facades of city shops will contribute to the city style and in turn will enable the recognition of the city brand.

One of the ways to enhance the visual-aesthetic aspect of the city that is included in the city style notion is to use the design code of the city.

Design code of the city - a set of rules and recommendations for the design of signboards and outdoor advertising, building facades and the surrounding area (city). The design code urges the owners and tenants of institutions and buildings to adhere to a uniform design of names, information plates and shop windows of institutions located on the facades of buildings to which the design code applies [22].

Many European cities like Barcelona in Spain possess design codes. Due to the design code, Barcelona is a well-planned beautiful city with its special city style, architecture and culture that attracts millions of visitors form many countries [23].

The design code of the city adds value to the visual-aesthetic aspect of the city which is part of the style of the city. The correct design code returns the culture of walking pedestrians, provides conditions to the design requirement conformities like - all sewer lines, sidewalks, streets and drainage ways, alleys, landscapes, public sites, lightings and other types of city improvements must be constructed and designed in accordance to the city design code.

Summing up, it should be said that, in addition to the four functional, social, spiritual and mental dimensions of the city brand model of Thomas Gad, the author proposes the fifth dimension. This dimension is the city style that incorporates the aspects of visual-aesthetic appearance of the city that could be put in place by means of the city design code. This added dimension improves the image of the city and may be a good tool to attract more tourists and investments to the city, more than that, a well-established city style may have an impact on the city recognition and develop a city as a brand.

\section{Conclusion}

This article was centered around examining one of the dimensions of the city brand. Finding out factors and components that contribute to and identifying the city's brand dimensions was the main purpose of the research. The city brand model of Thomas Gad has been taken as a theoretical basis of the study. This model describes four dimensions of a city brand: mental, spiritual, social and 
functional. The mental dimension has a relation to a mental programming and considers the idea that every human being has an inner landscape. The spiritual dimension implies understanding the relationships between the product, the brand and the company. The social dimension is based on the customers' perceptions of their social identities and this dimension has become strong nowadays because brands are powerful definers of social well-being of customers. The functional dimension of a city brand relates to the taste, efficiency and physical quality. The author of the article made an attempt to describe and add one more dimension to the aforementioned model - the "city style" dimension with its visual-aesthetic aspect.

This dimension seemed important to the author for several reasons: firstly, cities are well remembered by their appearances and due to their architectural images and the city style contributes to this fact. Secondly, in addition to other factors that form and develop city brand, the city style dimension with its visual-aesthetic aspect creates conditions to distinguish one city from the other.

Next, the literature review was conducted in order to clarify prevailing concepts of "brand" and "city brand". This review aimed to explain and understand the notions of brand in terms of its usage in respect to cities and identify different views of researchers regarding multifaceted dimensions of concepts of the "city brand". The questionnaire was carried out to determine the citizens' opinions if the city style affected the recognition of the city. The hypothesis was around the following statement: "there is a relationship between the city style and the city recognition". Majority of respondents stated that the city style affected the recognition of the city. Thus, the hypothesis of the study was confirmed and existing literature provided theoretical evidences for that. Also, it was identified that majority of respondents (59\% out of 112) in two major cities of Kazakhstan stated that their cities did not have a distinct city style. $58 \%$ of citizens expressed their positive attitude to the idea of their own cities to have its style. Moreover, it appeared to the respondents that the city style comprised the image of the city, its design and architectural views (39\%). Majority of respondents stated that there was an interrelation between the concepts of "city brand" and "city style" (46\%).

Since the issue of the city style in the development and formation of a city brand was studied, the author of the article described the definition of the term "city style" that incorporated a visual-aesthetic aspect - a unified styling of urban objects such as city garbage bins, lanterns, benches, irrigation ditches, bus stops and even the facades of city shops etc. The author stated that one of the ways to enhance the visual-aesthetic aspect of the city was to use the design code of the city. The design code of the city was about a set of rules and recommendations for the design of signboards and outdoor advertising, building facades and the surrounding area (city). This recommendation was offered based on international experience of city branding of European and American cities.

This article contributes to the body of knowledge in the sphere of marketing, especially in the field of the city brand development and formation. The theoretical contribution is in the fact that some attempts have been done to determine the importance of the city style in the city brand recognition and a practical implication suggesting Kazakhstan cities to implement the programs of city design codes that are successfully realized in many cities of the world.

\section{REFERENCES}

1 Szold T. Afterword, the changing regulatory template in regulating place, standards and the shaping of urban America. - Routledge, New York, 2005. - 370 p.

2 Gad T. 4-D branding: cracking the corporate code of the network economy. - Financial Times Prentice Hall, New York, 2001. - 192 p.

3 Martineau P. Sharper focus for the corporate image. - Harvard Business Review. 3S. 1959. №1. - P. 4958 .

4 American Marketing Association Marketing Definitions: A glossary of marketing terms. - American Marketing Association, Chicago, 1993. - 203 p.

5 Ataman M.B., Van Heerde H.J., Mela C.F. The long-term effect of marketing strategy on brand sales. Journal of Marketing Research, 2010. 47(5). - P. 866-882.

6 Kapferer J.N. The new strategic brand management: creating and sustaining brand equity long term. Kogan Page, London, 2004. - 560 p. 
7 Nickerson N., Moisey R. Branding a state from features to positioning: making it simple? - Journal of Vacation Marketing, 1999. Vol. 5. No. 3. - P. 217-226.

8 Dinnie K. City branding: theory and cases. - Palgrave Macmillan, NewYork, 2011. - 239 p.

9 Kavaratzis M., Ashworth G. City branding: An effective assertion of identity or a transitory marketing trick? - The journal of royal Dutch geographical society, 2005. Vol. 96(5). - P. 506-514.

10 Zenker S., Braun E., Petersen S. Branding the destination versus the place: The effects of brand complexity and identification for residents and visitors. - Tourism Management journal, 2017. Vol. 58. - P. 15-27.

11 Oguztimur S., Akturan U. Synthesis of city branding literature (1988-2014) as a research domain. International journal of tourism research, 2016. Vol. 18. - P. 357-372.

12 Vanolo A. City branding: The ghostly politics of representation in globalising cities. - Routledge, New York, 2017. $-218 \mathrm{p}$.

13 Kavaratzis M. Place branding: Are we any wiser? - Cities journal, 2018. Vol. 80. - P. 61-63.

14 Dinnie K. Nation branding: concepts, issues, practice. - Routledge, New York, 2015. - 289 p.

15 Strauss A., Corbin J. Basics of qualitative research: grounded theory procedures and techniques. - Sage Publications, Newbury Park, 1990. - 456 p.

16 Keller K.L. Strategic brand management: building, measuring and managing brand equity. - PrenticeHall, New Jersey, 2008. - 608 p.

17 Newman J.W. Motivation research and marketing management. The Plimpton Press, Norwood, 1957. $345 \mathrm{p}$.

18 Clark H.F.Jr. Consumer and corporate values: yet another view on global marketing. - International Journal of Advertising. 1987. No. 6(1). - P. 29-42.

19 Dinnie K. Place branding: overview of an emerging literature. - Journal of place branding and Public Diplomacy, 2004. Vol. 1. No. 1. - P. 106-110.

20 Sevin H.E. Understanding cities through city brands: City branding as a social and semantic network. Cities journal, 2014. Vol. 38. - P. 47-56.

21 Weilbacher W.M. Brand marketing. - NTC Business Books, Chicago, 1995. -210 p.

22 Siegan B. The benefits of non-zoning in regulating place, standards and the shaping of urban America. Routledge, New York, 2005. - 232 p.

23 Strum S. Barcelona Architecture. - Watermark Press, New York, 2005. - 320 p.

\section{А.П. САДУЛЛАЕВА, ғылымдар магистрі, докторант. \\ *e-mail: sp-aigul@mail.ru \\ Г.К. БАЙЖАҚСЫНОВА, ${ }^{1}$}

э.ғ.к., доцент.

e-mail: gulshat.baizhaksynova@narxoz.kz

${ }^{1}$ Нархоз университеті, Казақстан, Алматы қ.

\section{ҚАЛАЛЫК БРЕНДТІ ДАМЫТУ МӘСЕЛЕСІ БОЙЫНША: ҚАЛА СТИЛІ БРЕНДТІН ӨЛШЕМІ РЕТІНДЕ}

\section{Андатпа}

Мақалада қала брендін дамыту туралы сұрақтар қарастырылған. Зерттеудің негізгі мақсаты - қала брендінің өлшемдерін дамытуға ықпал ететін факторлар мен компоненттерді анықтау. Зерттеудің теориялық негізі ретінде Томас Гэдтің қалалық бренд моделі қолданылды. Бұл модель бойынша қалалық брендтің төрт өлшемі сипатталады: менталдық, рухани, әлеуметтік және функционалды. Мақала авторы жоғарыда аталған модельге тағы бір өлшем - визуалды және эстетикалық аспектілі «қалалық стиль» өлшемін сипаттап, қосуға тырысты. «Бренд» және «қалалық бренд» ұғымдарын түсіндіру мақсатында әдебиеттерге шолу жасалды. Сондай-ақ, қаланың танымалдылығына қала стилінің әсерін анықтау үшін Қазақстанның екі қаласының тұрғындары арасында сауалнама жүргізілді. Жоғарыда аталған зерттеу қаланың брендінің қалыптасуы мен дамуына қосқан теориялық және практикалық үлесі. Зерттеу авторының Қазақстан Республикасы қалаларына арналған дизайн-кодтарды әзірлеу туралы ұсынысы тәжірибелік маңызға ие.

Тірек сөздер: қалалық бренд, өлшеулер, брендтің танымалдылығы, модель, брендинг, қалалық стиль, қаланың дизайн-коды. 


\title{
А.П. САДУЛЛАЕВА, *1 магистр наук, докторант. \\ *e-mail: sp-aigul@mail.ru \\ Г.К. БАЙЖАКСЫНОВА, ${ }^{1}$ \\ к.э.Н., доцент. \\ e-mail: gulshat.baizhaksynova@narxoz.kz \\ ${ }^{1}$ Университет Нархоз, Казахстан, г. Алматы \\ К ВОПРОСУ О РАЗВИТИИ БРЕНДА ГОРОДА: ГОРОДСКОЙ СТИЛЬ КАК ИЗМЕРЕНИЕ БРЕНДА ГОРОДА
}

\begin{abstract}
Аннотация
В статье рассматриваются вопросы развития бренда города. Выявление факторов и компонентов, которые способствуют развитию бренда города, и было основной целью исследования. Модель бренда города Томаса Гэда была применена в качестве теоретической основы исследования. Эта модель описывает четыре измерения городского бренда: ментальное, духовное, социальное и функциональное. Автор статьи предпринял попытку описать и добавить еще одно измерение к вышеупомянутой модели - измерение «городской стиль» с его визуально-эстетическим аспектом. Обзор литературы был проведен с целью уточнить понятия «бренд» и «городской бренд». Также было проведено анкетирование среди жителей двух городов Казахстана, чтобы выявить влияние стиля города на узнаваемость города. Вышеописанное и есть теоретико-практический вклад данного исследования в область развития и формирования бренда города. Прикладное значение имеет предложение автора исследования разработать дизайн-коды для городов Республики Казахстан.
\end{abstract}

Ключевые слова: городской бренд, измерения, узнаваемость бренда, модель, брендинг, городской стиль, дизайн-код города. 